Vol. 8, No. 1, 2021

https://doi.org/10.23939/eem2021.01.108

UDC 378:37.004

JEL Classification Code: I28

\author{
S. Protska \\ National Pedagogical Dragomanov University, Ukraine, PhD, Associate Professor, \\ E-mail: s.m.protska@npu.edu.ua \\ ORCID ID: 0000-0002-9212-8700
}

\title{
FORMATION OF IC-COMPETENCE OF THE FUTURE MASTER OF PUBLIC ADMINISTRATION
}

\begin{abstract}
The article is substantiated the practical aspects of the formation of IC-competence of the future master of public administration (for students of the second (master's) level of higher education of the educationalprofessional program 281 Public administration and administration. State educational policy) in terms of informatization of higher education; the role of Google services (for example, Google Classroom, Google Docs $\&$ SpreadSheets, Google Forms, Google Calendar) in the formation of IC-competence of the future master of public administration is revealed; their characteristics are outlined: 1) saving money on the purchase of software; 2) reducing the need for specialized classrooms, as in any classroom you can organize a modern educational process using laptops and wireless network; 3) the ability to perform many activities, monitor and evaluate student achievement online; 4) openness of the educational environment for those who teaches (teacher) and those who studied (student); examples of pedagogical using of elements of Google services for the formation of IC-competence of the future master of public administration in higher education institutions in the process of studying the discipline (educational component) "Management of the IT-structure of the educational institution".
\end{abstract}

Key words: master's degree in public administration; informatization of education; information and communication technologies; IC-competence; Google services.

\section{Formulation of the problem}

Formation of professional competencies of the future specialist in the conditions of introduction of modern information technologies in practice of educational process is one of the key priorities of development of higher education of modern Ukraine. Thus, we consider the organization and implementation of Google services in the educational environment, which create new opportunities for the realization of the personal potential of the future master of public administration with higher education, to be a strategically important direction in the higher education system.

\section{Relevance of the chosen topic}

It is based on the analysis of psychological and pedagogical literature, it is revealed that in Ukraine due attention is paid to the study of problems of informatization of education, application in the educational process of educational institutions of information and communication technologies (ICT). Actual aspects of these problems are shown in the works of V. Bykov, V. Bobrytska, M. Zhaldak, N. Morse, O. Spivakovsky, O. Spirin, Y. Trius and others. However, the research on the problems of using Google services for the formation of IR competence of the future master of public administration, in terms of informatization of education was conducted in fragments, which justifies the relevance of their implementation given the current challenges of the information society.

\section{Analysis of recent research and publications}

Various aspects of the problem of formation of IC-competence of future specialists with higher education and their preparation for the use of ICT in professional activities, namely: investigated the theoretical and practical aspects of the use of ICT in the educational process of ZVO - V. Bykov, 
O. Glazunova, O. Glushak, M Zhaldak, O. Zhiltsov, Y. Zhuk, O. Kolgatin, K. Kolos, M. Leshchenko, S. Litvinova, A. Manako, N. Morse, Y. Nosenko, O. Ovcharuk, L. Petukhova, O. Pinchuk, O. Sokolyuk, N. Soroko, O. Spivakovsky, E. SpivakovskayaVandenberg, O. Spirin, Y. Trius, M. Shishkina, A. Yatsyshyn and others; substantiated the theoretical-methodological and methodological bases of application of the competence approach in the training of specialists with higher education O. Antonova, N. Bibik, V. Bobrytska, L. Klos, L. Kravchenko, O. Lokshina, O. Ovcharuk, O. Pometun, O. Savchenko, V. Yagupov and others.

\section{Purpose and tasks}

The purpose of the research is to substantiate the practical aspects of the formation of ICcompetence of the future master of public administration in the context of informatization of education.

The following tasks have been identified: to reveal the role of Google services in the formation of IC-competence of the future master of public administration; give examples of pedagogical use of elements of Google services for the formation of IR competence of the future master of public administration in higher education institutions (HEI).

\section{Presentation of the main material of the study and the results obtained}

Summarizing the views of scientists on the essential characteristics of the process of formation of the information society, we share their conclusions that ICT is increasingly penetrating into various spheres of life, science, education, production, which requires relevant knowledge and skills to apply them [3]. First of all, we note that our research position agrees with the scientific opinion of Bobrytska V., who notes that the relevance of informatization of education is due to the fact that currently there is a constant relationship between success in teaching students and the quality of their training in ICT, their IC-competence, which is implemented by improving the efficiency, intensity and instrumentality, reducing the complexity of the processes of using information resources in the educational process of free economic zones. The researcher emphasizes that one of the factors that significantly affects the improvement of professional training for a master's degree in public administration is the content and structure of the educational environment as a means of forming their professional competencies [2, 4].

Notice that all innovative changes, above all, are depended on the student, his creative potential, creativity, readiness for continuous self-education, needs for professional growth, flexibility of sociopedagogical thinking, humanistic orientation of the individual. In our opinion, it is important for a master's degree in public administration to acquire appropriate professional competencies in terms of informatization of the educational environment, in which learning takes place on the basis of comprehensive consideration of their individual needs and capabilities, the requirements of society. According to V. Bykov, these changes form a new priority of higher education, the so-called ICToriented education, ie education that reflects global trends in educational systems, provides a broad, comprehensive and effective use of ICT in the implementation of its own internal system functions (educational, scientific and managerial) and external functions for the implementation of relationships with the surrounding educational system; aimed at implementing the principles of open education $[1,6]$.

A number of educational information encourage the search for individual ways to master new activities, including analysis, selection, generalization of information [1]. The educational activity of modern students is largely determined by their own activity in mastering ICT, based on the meaningful acquisition of a set of IC-competencies that are necessary for successful self-realization in future professional activities $[5,6]$.

Theoretically significant for solving the problems of our study are the conclusions of scientists that the new social services have simplified the process of creating and publishing materials on the global Internet. Now everyone can not only access photos, videos, texts, but also take part in editing them and creating their own online content. With the help of Web 2.0 services, content is created by millions of people. They develop and post new texts, photos, pictures, music files online. At the same time, communication between people is increasingly not in the form of direct exchange of information, but in the form of observation of network activities $[1,5,6]$. 


\section{S. Protska}

In particular, the use of Google services in freelancers can give:

1) saving money on the purchase of software;

2) reducing the need for specialized classrooms, as in any classroom you can organize a modern educational process using laptops and wireless network;

3) the ability to perform many activities, monitor and evaluate student achievement online;

4) openness of the educational environment for those who teach (teacher) and those who study (student).

In addition, the means and technologies of information and communication networks, including the Internet, form a computer-oriented platform for the educational process of studying disciplines in higher education $[1,5,7]$.

Successful experience in solving the problem of using Google services in master's degree in public administration is in the National Pedagogical Dragomanov University. In particular, in the process of studying the discipline (educational component)
"Management of the IT-structure of the educational institution", during seminars and practical classes for students of the second (master's) level of higher education educational-professional program 281 Public Administration. Public education policy, a teacher to attract the entire target audience and at the same time quickly assess the preparation of all students, uses various Google services. Next we will consider them in more detail $[9,10]$.

It was starting from March 2020, in the conditions of quarantine during the pandemic caused by the coronavirus SARS-CoV-2, teachers of the Department of Social Philosophy, Philosophy of Education and Educational Policy of the Faculty of Management of Education and Science of the National Pedagogical Dragomanov University actively used the possibilities of using Google Classroom to create electronic training courses for disciplines (Fig. 1). Because all teachers have Google corporate mail, and students with modern mobile communications also use Google mail, the Google Classroom app is the most accessible.

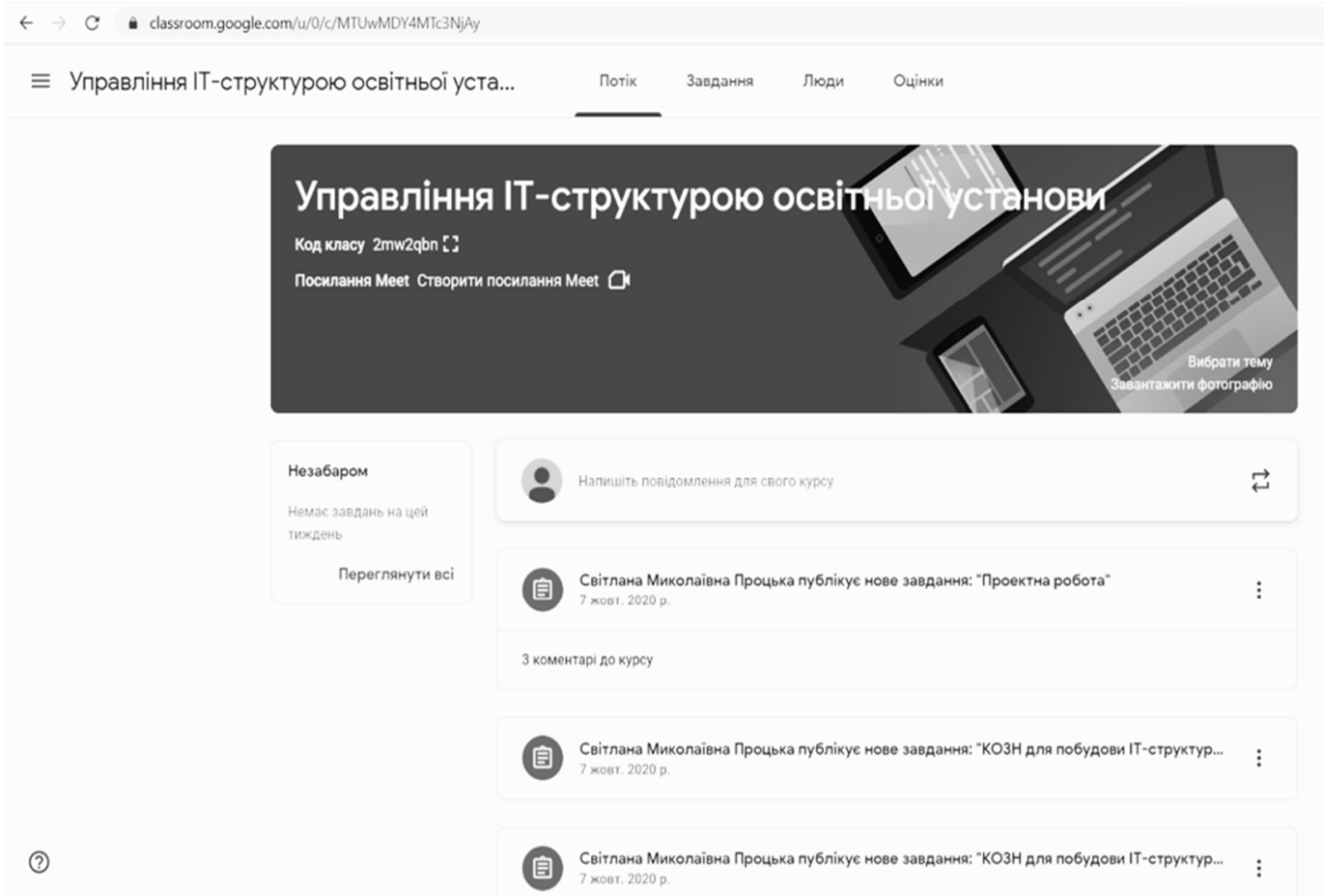

Fig. 1. Starting page of the e-learning course

"Management of the IT structure of the educational institution" in Google Classroom

Thus, in the Google Classroom, the teacher in the section "Tasks" openly places all the necessary information from his discipline (educational component), which he considers should be mastered by the student mastering this course. For example, the e-learning course "Management of the IT structure of an educational institution" for students of the second (master's) level of higher education was taken (Fig. 2). The course contains two sections - "Theoretical material", where the teacher 


\section{Formation of ic-competence of the future master of public administration}

for students posted a work program, syllabus contains specific practical tasks for students to and textbook, "Practical material", which perform.

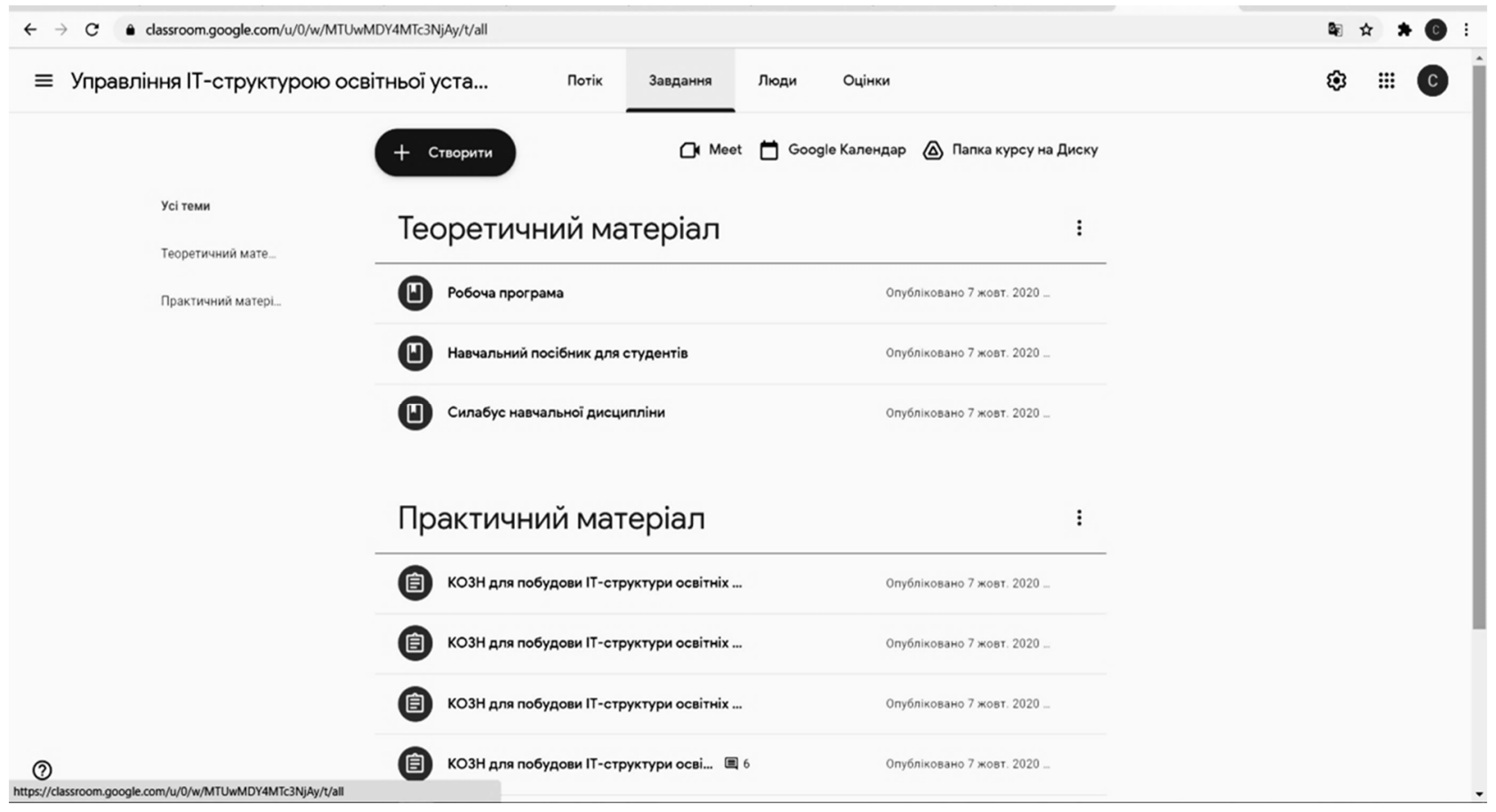

Fig. 2. Example of placing materials in Google Classroom

In the "People" section, the teacher has the opportunity to involve students in the course by sending them an invitation by mail or a link to this course through various social networks, control the number of registered students, and if necessary remove them (Fig. 3).

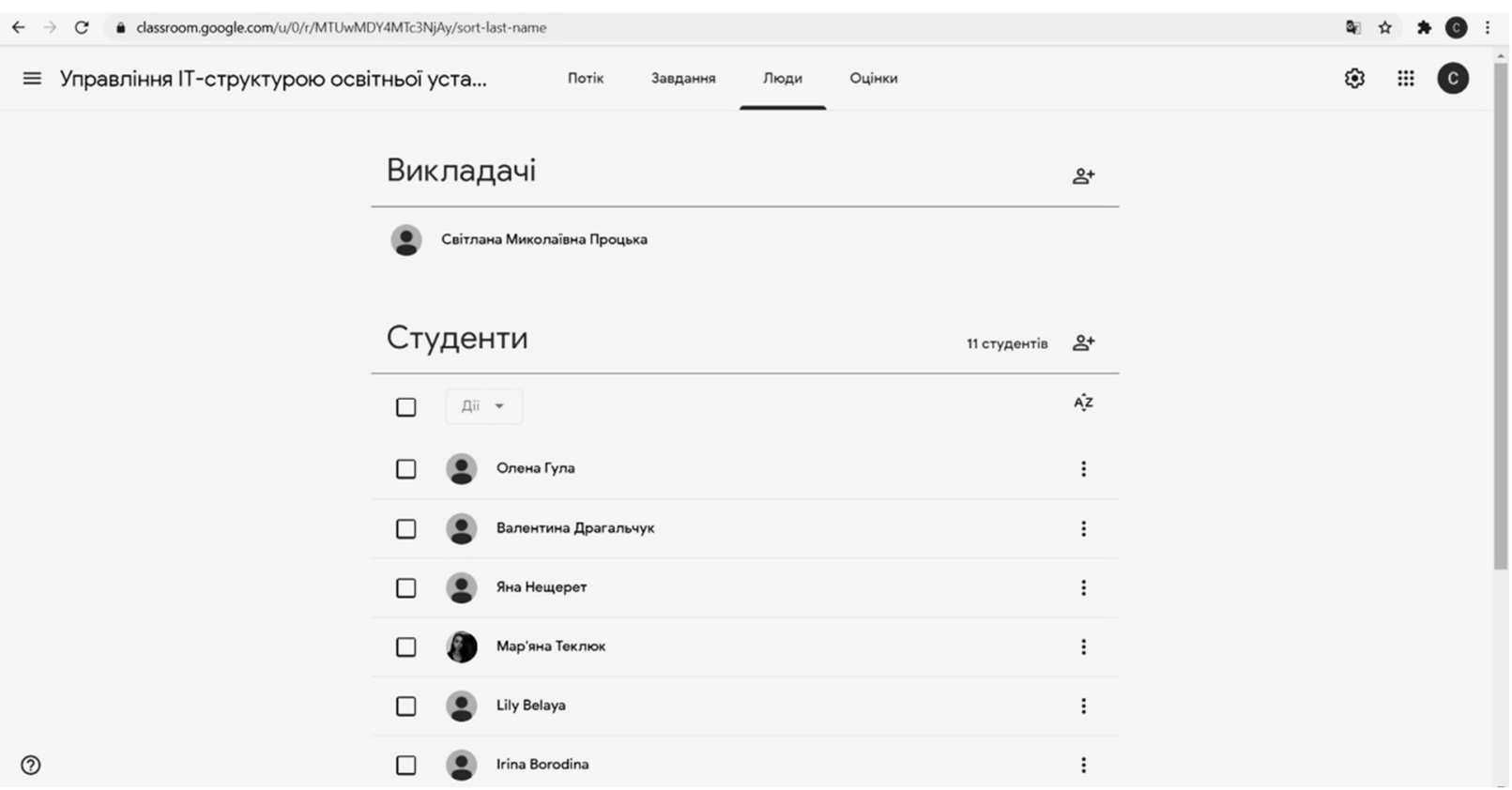

Fig. 3. Example of student management in Google Classroom

In the section "Assessments" the teacher evaluates practical tasks (Fig. 4). Here it is easy and accessible, with savings of own time on check and summary of data on each student, quickly 


\section{S. Protska}

receives the general picture of educational results the individual page of each student and evaluate it of students. If necessary, the teacher can also visit separately (Fig. 5).

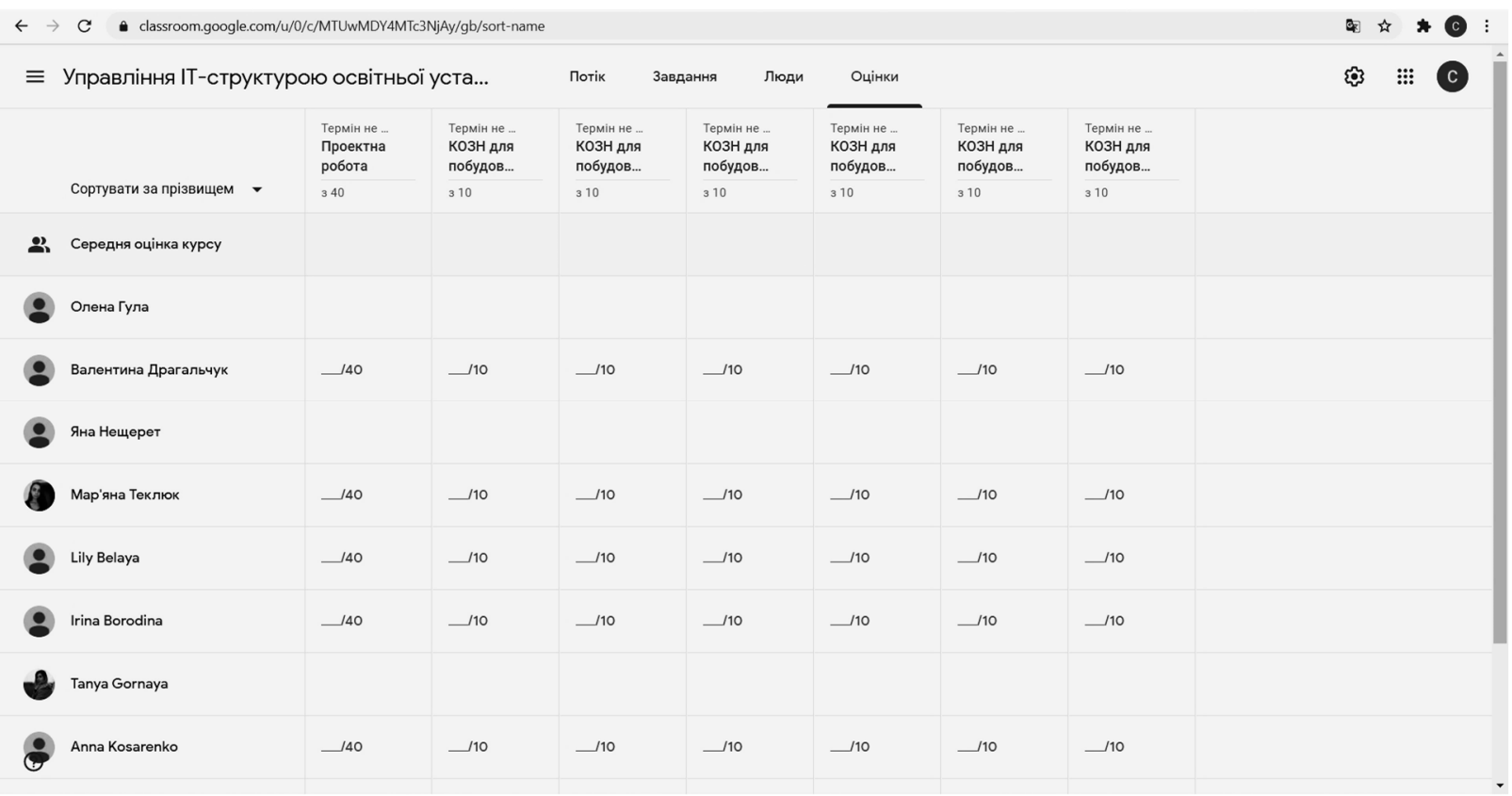

Fig. 4. Example of student assessment in Google Classroom

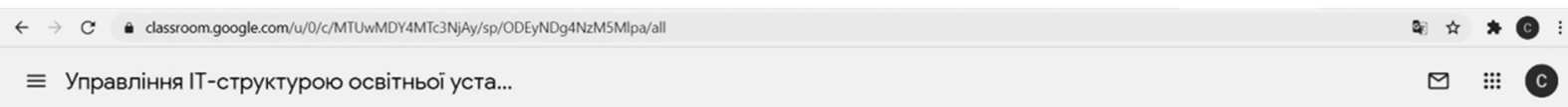

$\equiv$ Управління ІТ-структурою освітньої уста...

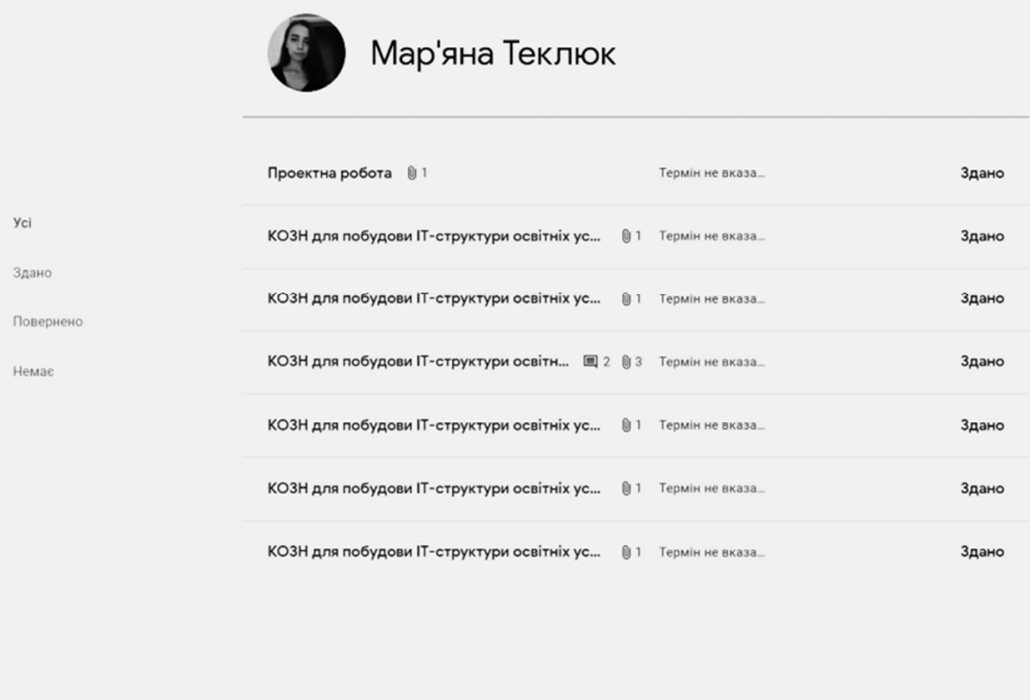

Fig. 5. Example page of a student of the second (master's) level of higher educational and professional program 281 Public administration and administration. Public education policy in Google Classroom

The next Google service is Google Docs \& SpreadSheets. The documents can be edited jointly by users who have received the invitation (it is not necessary to have a Google account for this), in the process of reviewing and editing available to view changes and chat. The file exchanger works for free with a quota of $1 \mathrm{~GB}$, additional volume can be obtained at your expense. Google Docs \& SpreadSheets supports "cloud" printing of documents (remote sending of files to the printer queue), and is also stored in the content service [8, 9] (Fig. 6). 


\section{Formation of ic-competence of the future master of public administration}

One of the available and effective Google services is Google Forms. Note that the teacher can use Google Forms (Fig. 7) to attract the entire target audience and quickly assess the training of all students in a particular module or topic $[5,11,12]$.

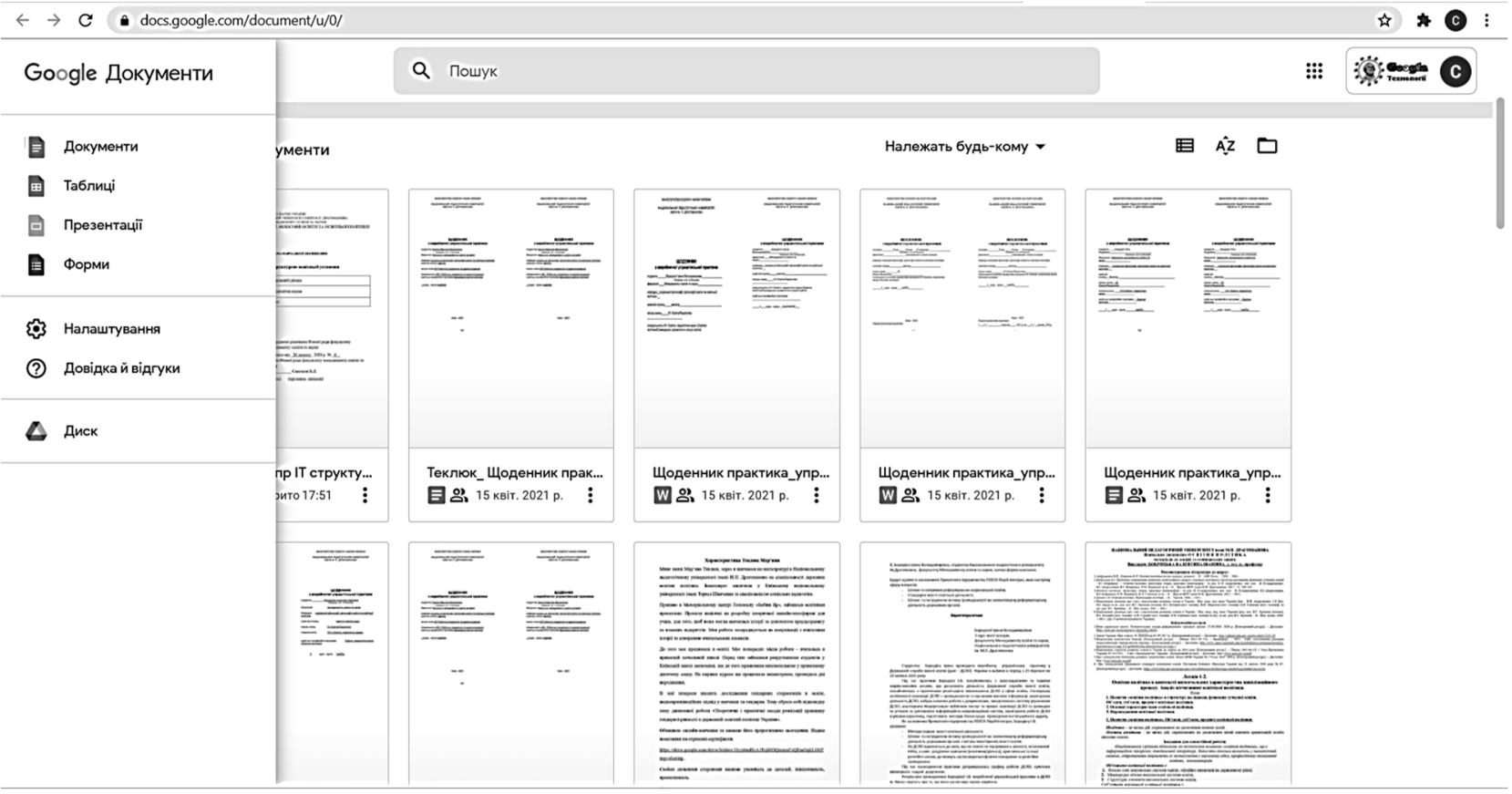

Fig. 6. Example Google Docs \& SpreadSheets

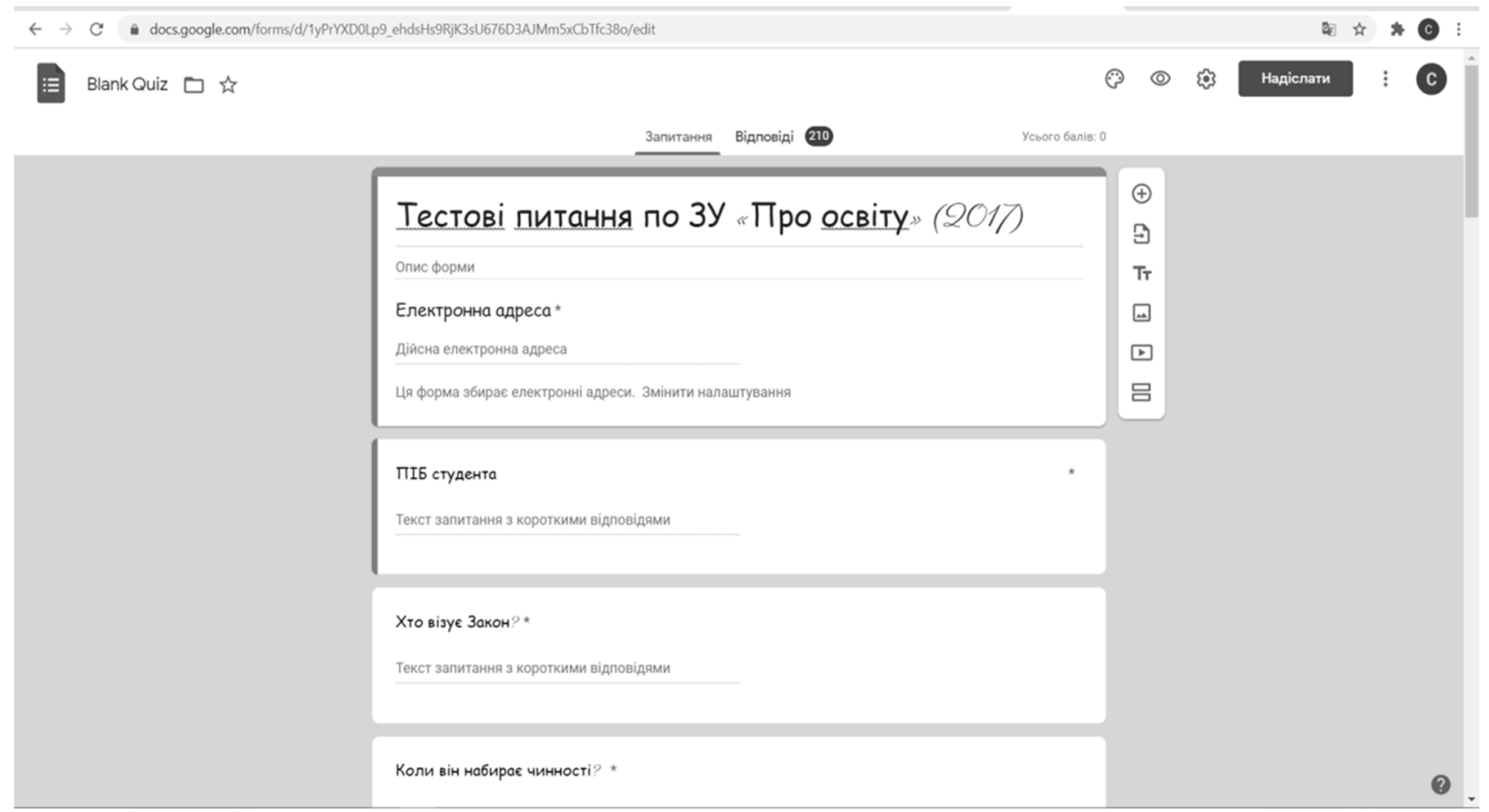

Fig. 7. Example of Google Forms

Appropriately, Google services will consider Google Calendar (Fig. 8). This application helps both the teacher and the student to plan their work, educational and free time, which in our period allows you to organize an effective educational process in ZVO $[5,10,11]$. 


\section{S. Protska}

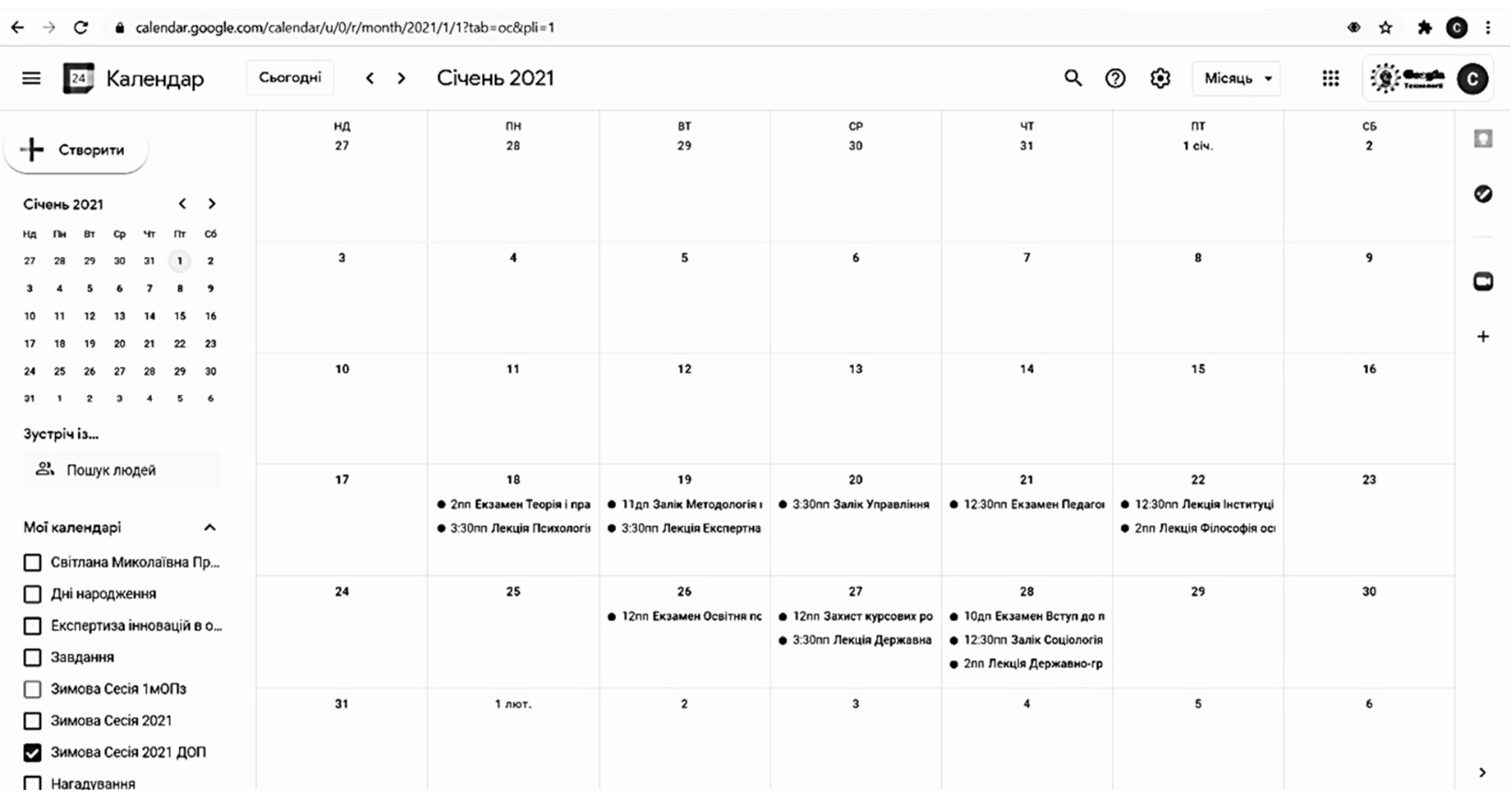

Fig. 8. Example of Google Calendar for future masters in public administration

From the above, using Google services, students can effectively plan and prepare for classes, which, in our opinion, contributes to the acquisition of IC-competence in the educational process.

\section{Conclusions and prospects for further research}

The specifics of the future professional activity of the Master of Public Administration were given, it is important to note that the use of Google services (eg, Google Classroom, Google Docs \& SpreadSheets, Google Forms, Google Calendar) creates conditions for them at the stage of acquiring a profession important for individual professional motives. values, acquisition of knowledge, skills and experience, development of abilities, creative inclinations; provides the latest approaches to educational communication, cooperation and collaboration. So, given the results of this research, we believe that Google's services in the formation of the IC-competence of the Master of Public Administration in the context of informatization of education play an important role for the modern system of higher education. We see prospects for further research in the development of pedagogical conditions for monitoring the results of the use of Google services in the educational process of higher education institutions, including during the training of a master's degree in public administration.

\section{References}

1. Bykov V. Yu. (2009). Modeli orhanizatsiinykh system vidkrytoi osvity : monohrafiia. [Models of organizational systems of open education: monograph] K. : Atika. [in Ukrainian]

2. Bobrytska V. I. (2011). Zastosuvannia informatsiinokomunikatsiinykh tekhnolohii u vyschii pedahohichnii osviti. Pedahohichna osvita : teoriia i praktyka. Pedahohika. Psykholohiia. [Pedagogical education: theory and practice. Psychology. Pedagogy] 16 (2). 35-39. [in Ukrainian]

3. Bobrytska V. I., Hlushak O. M. (2014). Osnovy informatsiinoi kultury bakalavriv $z$ filolohii: navch.-metod. posibn.: dlia stud. vysch. navch. zakl. Poltava : Polihrafichnyi tsentr "Skaitek". [in Ukrainian]

4. Bobrytska V. I. (2015). Osvitnia polityka Ukrainy u sferi informatyzatsii osvity. Osvitnia polityka: filosofiia, teoriia, praktyka: monohrafiia. [Educational policy of Ukraine in the field of informatization of education. Educational policy: philosophy, theory, practice: monograph] Za red. V. P. Andruschenka; Avt. kol. : V. P. Andruschenko, B .I. Andrusyshyn, V.I. Bobrytska, R.M. Vernydub ta in. (p. 273-316). K. : Vyd-vo NPU imeni M. P. Drahomanova. [in Ukrainian]

5. Bobrytska V. I., Protska S. M. (2016). Kompiuterno oriientovana osvita maibutnikh filolohiv: navchalno- 
Formation of ic-competence of the future master of public administration

metodychnyi posibnyk dlia studentiv ZVO. [Computer oriented education of future philologists: a textbook for students of HEI] Poltava: Skaitek. [in Ukrainian]

6. Bobrytska V. I., Protska S. M. (2017). Formuvannia profesiinykh kompetentnostei maibutnikh filolohiv zasobamy kompiuterno oriientovanykh tekhnolohii. Informatsiini tekhnolohii $i$ zasoby navchannia. [Information Technologies and Learning Tools] 2 (58). 59-66. Retrieved from: http://journal.iitta. gov.ua/index.php/itlt/issue/view/87/showToc doi: 10.33407/itlt.v58i2.1644 [in Ukrainian]

7. Bobrytska V. I., Protska S. M. (2019). Orhanizatsiinopedahohichni umovy vykorystannia elektronnykh navchalnykh kursiv $v$ osvitn'omu protsesi zakladiv vyschoi osvity Ukrainy. Visnyk Natsionalnoho aviatsiinoho universytetu. Seriia: Pedahohika. Psykholohiia: zb. nauk. pr. Kyiv: Vyd-vo Nats. aviats. un-tu "NAU-druk". 2 (15). 19-24. doi: 10.18372/2411-264x.15.14394 [in Ukrainian]

8. Lytvynova S. H., Spirin O. M., Anikina L. P. (2015). Khmarni servisy Office 365 : navchalnyi posibnyk. Kyiv. : Komprynt. Retrieved from: http://lib.iitta.gov. ua/10252/1/FAKULTATYV\%20\%20Office365-Byblyoteka.pdf [in Ukrainian]

9. Protska S. M. (2017). Merezhni IKT yak osnova kompiuterno oriientovanoi metodyky formuvannia profesiinykh kompetentnostei maibutnikh filolohiv. Pedahohichna osvita: teoriia i praktyka. Psykholohiia. Pedahohika: zb. nauk. pr. [Proceedings of the
National Aviation University. Series: Pedagogy, Psychology] Kyiv. un-t im. B. Hrinchenka. redkol.: Ohneviuk V. O., Khoruzha L. L. ta in. Kyiv: Kyiv. un-t im. B. Hrinchenka. 27. 105-108. [in Ukrainian]

10. Bobrytska V. I., Protska S. M. (2018). Formation of professional competencies of the future teachers by means of a computer-based methodology: investigational approach". Informatsiini tekhnolohii $i$ zasoby navchannia. [Information Technologies and Learning Tools] 5 (67). 121133. Retrieved from: https://journal. iitta.gov.ua/index.php/itlt/issue/view/96/showToc_doi: 10.33407/itlt.v67i5.2307fyjd

11. Bobrytska, V. I., Reva, T. D., Protska, S. M. \& Chkhalo, O. M. (2020). Effectiveness and Stakeholders' Perceptions of the Integration of Automated E-Learning Courses into Vocational Education Programmes in Universities in Ukraine. International Journal of Learning, Teaching, and Educational Research, 19 (5), 27-46. doi: 10.26803/ijlter.19.5.3

12. Protska S. M. (2017). Computer oriented methods of formation of professional competence of future teachers of philology in the structure of open education. European humanities studies: State and Society. EUROPEJSKIE STUDIA HUMANISTYCZNE: Panstwo $i$ Spoleczenstwo. T. 5. 132-143. 